\title{
Seismological Aspects of the December 2004 Great Sumatra-Andaman Earthquake
}

\author{
Hiroo Kanamori, ${ }^{a)}$ M.EERI
}

The 2004 Great Sumatra-Andaman earthquake had an average source duration of about $500 \mathrm{sec}$. and a rupture length of 1,200-1,300 km. The seismic moment, $M_{0}$, determined with a finite source model, was 6.5 $\times 10^{22} \mathrm{~N}-\mathrm{m}$, which corresponds to $M_{w}=9.18$. Allowing for the uncertainties in the current $M_{0}$ determinations, $M_{w}$ is in the range of 9.1 to 9.3 . The tsunami magnitude $M_{t}$ is 9.1 , suggesting that the overall size of the tsunami is consistent with what is expected of an earthquake with $M_{w}=9.1$ to 9.3. The short-period body-wave magnitude $\hat{m}_{b}$ is 7.25 , which is considerably smaller than that of large earthquakes with a comparable $M_{w}$. The $\hat{m}_{b}$ versus $M_{w}$ relationship indicates that, overall, the Great Sumatra-Andaman earthquake is not a tsunami earthquake. The tectonic environment of the rupture zone of the Great Sumatra-Andaman earthquake is very different from that of other great earthquakes, such as the 1960 Chile and the 1964 Alaska earthquakes. This difference may be responsible for the unique source characteristics of this earthquake. The extremely large size of the Great Sumatra-Andaman earthquake is reflected in the large amplitude of the long-period phase, the $W$ phase, even in the early part of the seismograms before the arrival of the $S$ wave. This information could be used for various early warning purposes. [DOI: 10.1193/1.2201969]

\section{INTRODUCTION}

The 2004 Great Sumatra-Andaman earthquake (26 December 2004, 00:58:50.00 UT, $3.30^{\circ} \mathrm{N}, 95.78^{\circ} \mathrm{E}$, depth $\sim 10 \mathrm{~km}$ ) was one of the largest earthquakes instrumentally recorded. It ruptured the boundary between the Indo-Australian plate and the Eurasian plate along northwestern Sumatra, the Nicobar Islands, and the Andaman Islands. The faulting occurred on a low-angle thrust fault dipping about $10^{\circ}$ northeast with the IndoAustralian plate moving northeast relative to the Eurasian plate. Since several papers have been already written on this earthquake (e.g., Lay et al. 2005), and the geological and geodetic aspects are covered by Hudnut (2006, this issue), here we focus on the basic description of the seismological aspects of this earthquake.

\footnotetext{
a) Seismological Laboratory, California Institute of Technology, Pasadena, CA 91125
} 


\section{Sumatra-Andaman Earthquake}

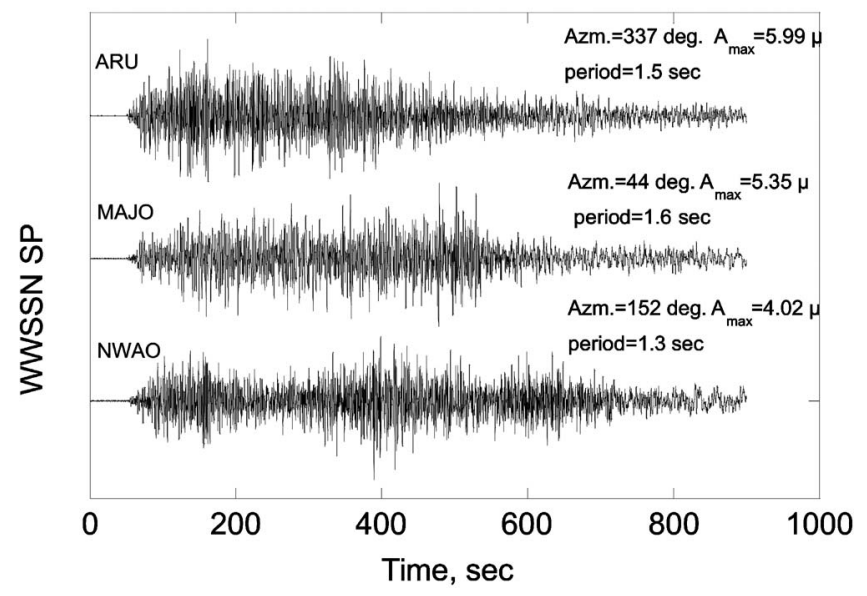

\section{Chile}

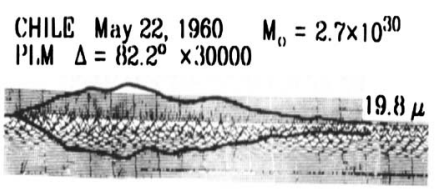

Figure 1. WWSSN short-period seismograms of the Great Sumatra-Andaman earthquake (3 azimuths) and the 1960 Chile earthquake. The time scale is common to both events. $A_{\max }$ is the ground-motion amplitude at the time when the maximum of the seismogram amplitude occurs.

\section{SIZE}

Since an earthquake is a complex rupture process, there is no simple way to describe its size. Here, we discuss the size of the Great Sumatra-Andaman earthquake by using several different measures.

\section{SOURCE DURATION}

Here, "duration" means the duration of the rupture process at the source, not the duration of ground motion at different sites. Ni et al. (2005) investigated the duration of the rupture process by looking at high-frequency $(2-4 \mathrm{~Hz})$ seismic waves recorded at teleseismic stations. The duration ranges from about 400 to $600 \mathrm{sec}$. with a clear directional pattern, long $(600 \mathrm{sec}$.$) in the azimuth of 135^{\circ}$ and short $(400 \mathrm{sec}$.$) in the azi-$ muth of $315^{\circ}$, with the average being about $500 \mathrm{sec}$. This source duration is the longest ever recorded. For comparison, the 1960 Chile earthquake $\left(M_{w}=9.5\right)$ and the 1964 Alaska earthquake $\left(M_{w}=9.2\right)$ had a source duration of about $340 \mathrm{sec}$. (Houston and Kanamori 1986). Figure 1 compares the short-period records of the Great Sumatra- 
Andaman earthquake in 3 azimuths with that of the 1960 Chile earthquake. In this figure, the seismograms with the World Wide Standardized Seismographic Network (WWSSN) short-period response are shown. Thus, as far as the source duration is concerned, the Great Sumatra-Andaman earthquake was by far larger than any events instrumentally recorded.

\section{RUPTURE LENGTH}

The rupture length was determined via several different methods. For example, Ni et al. (2005) used the azimuthal pattern of the duration of high-frequency waves, Ishii et al. (2005) applied a back-projection method to the Japanese Hi-net data, Ammon et al. (2005) used broadband $(20-1,000 \mathrm{sec}$.$) seismic radiation, and Tsai et al. (2005) in-$ verted long-period waves via a 5-source model. All these studies suggest that the total rupture length was approximately $1,200-1,300 \mathrm{~km}$, which is about the same as the length of the aftershock distribution within a few days after the earthquake. In comparison, the rupture length of the 1960 Chile earthquake was about $800-1,000 \mathrm{~km}$, and that of the 1964 Alaska earthquake was about $500-700 \mathrm{~km}$. Thus, the Great SumatraAndaman earthquake has probably the longest rupture length ever determined instrumentally.

\section{SEISMIC MOMENT, $M_{0}$ AND $M_{W}$}

The seismic moment $M_{0}$ is determined from the amplitude of long-period seismic waves. The early determination of $M_{0}$ for this earthquake was made by the routine centroid moment tensor (CMT) inversion, which gave $3.95 \times 10^{22} \mathrm{~N}-\mathrm{m}$ (http:// www.seismology.harvard.edu/CMTsearch.html). This corresponds to $M_{w}=9.0$. In comparison, the 1960 Chile earthquake and the 1964 Alaska earthquake have $M_{w}=9.5$ and $M_{w}=9.2$, respectively. Thus, in terms of $M_{w}$, the Great Sumatra-Andaman earthquake appears somewhat smaller than the Chile and the Alaska earthquakes. However, this comparison is not as straightforward as it seems. For such large earthquakes as the Great Sumatra-Andaman earthquake, it is necessary to use very-long-period seismic waves (longer than $300 \mathrm{sec}$.) to determine $M_{0}$ and $M_{w}$. The period used in the CMT determination was about $300 \mathrm{sec}$. and was not long enough to capture the total long-period energy radiated from the source. Also, because of the long rupture length, the radiation directivity must be correctly taken into account. Another difficulty is that, for accurate determinations of $M_{0}$ for shallow low-angle fault events (megathrust events), the dip angle and the 3-D near-source structure must be accurately known.

Unfortunately, in current practice, a laterally homogeneous source structure is used for source inversion. Thus, the mechanism, especially the dip angle, the depth extent of the source, and the seismic moment are subject to considerable uncertainties - even for the Great Sumatra-Andaman earthquake, for which large amounts of high-quality data are available. For older events, like the 1960 Chile and the 1964 Alaska earthquakes, the quality and quantity of the data were limited, so that $M_{0}$ and $M_{w}$ are subject to even larger uncertainties. For the Great Sumatra-Andaman earthquake, more recent studies obtained $M_{0}=6.5$ to $11 \times 10^{22} \mathrm{~N}-\mathrm{m}$ (Stein and Okal 2005, Ammon et al. 2005, Tsai et al. 2005), which gave $M_{w}=9.1$ to 9.3. In this paper, we use $M_{w}=9.2$ as a representative 

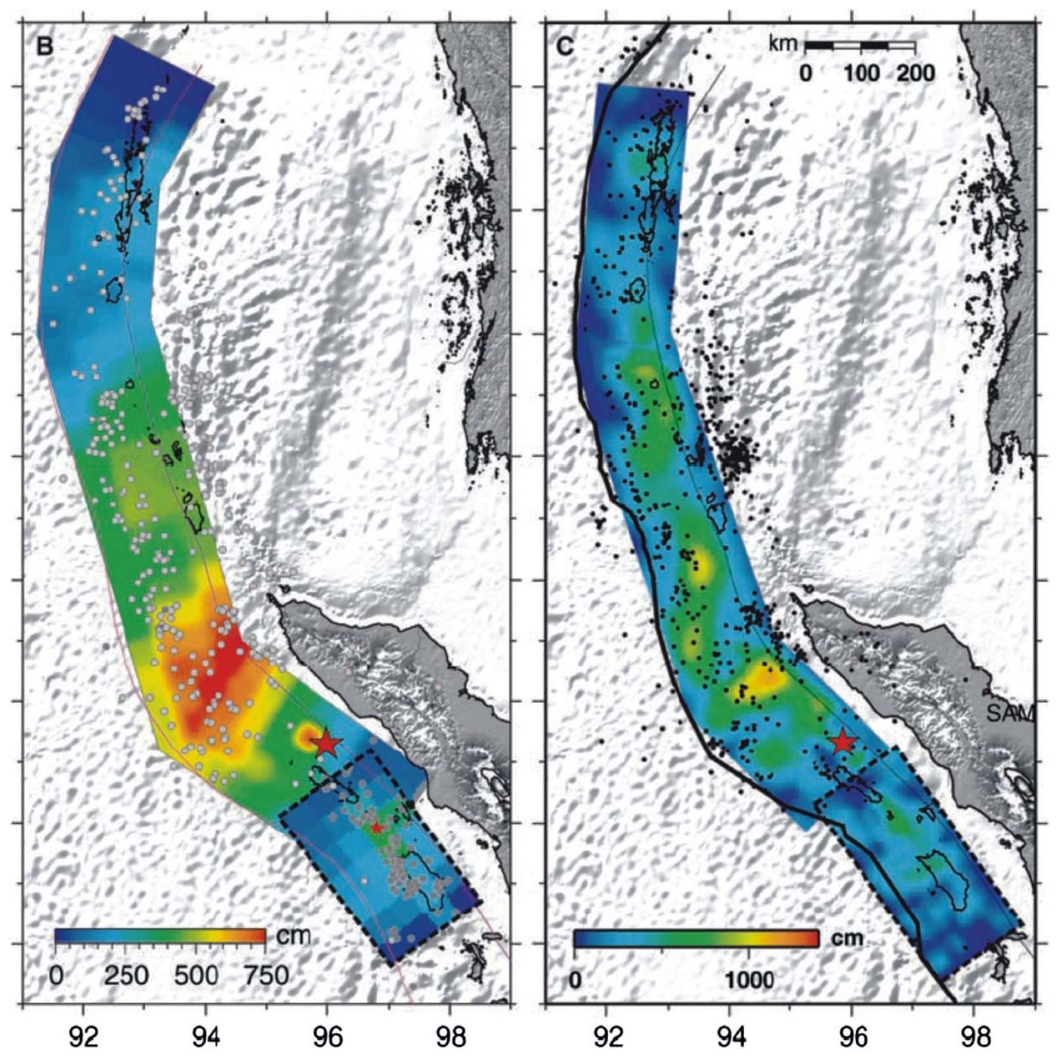

Figure 2. Finite-source slip models for the Great Sumatra-Andaman earthquake (Ammon et al. 2005). Note the difference in the color scale between the two figures.

value (see the note in the next section). Figure 2 shows two of the finite-source slip models that can explain body and surface waves (Ammon et al. 2005).

Thus, at face value, it appears that the Great Sumatra-Andaman earthquake is comparable to the 1964 Alaska earthquake and is somewhat smaller than the 1960 Chile earthquake. However, because of the limitations mentioned above, exact comparisons are not very meaningful, and these three earthquakes should be considered equally great earthquakes. An interesting comparison can be made regarding the moment-rate function (i.e., the variation of seismic moment rate as a function of time) in Figure 3. As shown in the figure, the Great Sumatra-Andaman earthquake built up slowly in the beginning and had a long duration, more than $500 \mathrm{sec}$. The area under the curve gives the seismic moment. In contrast, the Alaska earthquake built up more rapidly, reaching a higher moment rate, but it ended more rapidly than the Great Sumatra-Andaman earthquake.

Because of its very large size, the Great Sumatra-Andaman earthquake excited Earth's normal modes with a high signal-to-noise ratio. The finite-source models deter- 


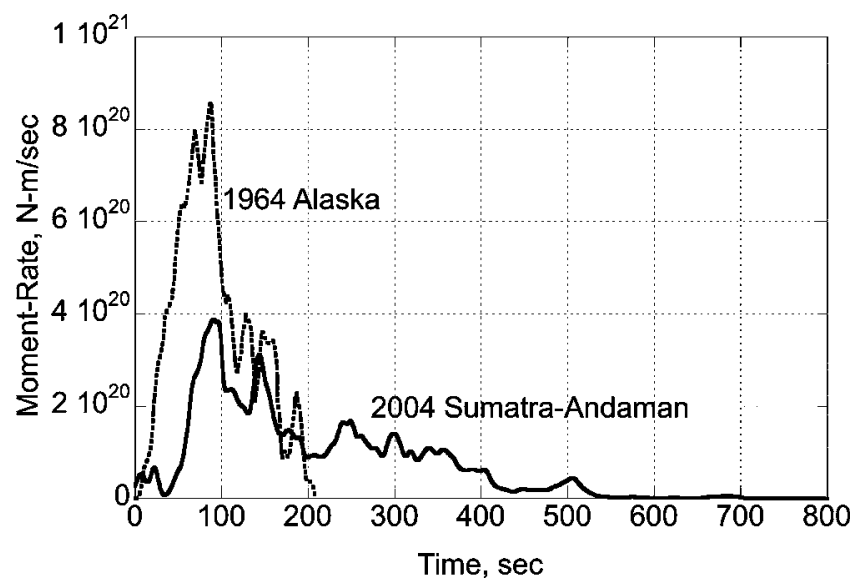

Figure 3. Moment-rate functions of the 1964 Alaska earthquake and the 2004 Great SumatraAndaman earthquake.

mined with body and surface waves shown in Figure 2 can explain the amplitudes of the long-period normal modes such as the gravest spheroidal mode ${ }_{0} \mathrm{~S}_{2}$ (period 54 min.) and the radial mode ${ }_{0} \mathrm{~S}_{0}$ (period $21 \mathrm{~min}$.) very well (Park et al. 2005), suggesting that the slip models shown in Figure 2 are a good representation of the source slip distribution on a time scale up to 1 hour. Seismic data cannot determine the source process beyond 1 hour; a time scale beyond that limit can be addressed more adequately with the geodetic data (Hudnut 2006, this issue).

\section{TSUNAMI}

Since the Great Sumatra-Andaman earthquake generated the most devastating tsunami in recorded history, an obviously interesting and important question is how the tsunami generated by this earthquake compares with those generated by other earthquakes. Since tsunami excitation and propagation are affected in a very complex way by the time and spatial scales of the source and by the bathymetry of the open sea and coastal areas, it is not straightforward to compare the size of tsunamis excited by different earthquakes. Since the details of tsunami effects are covered by the papers in the Tsunami Field Surveys and Analyses section of this issue, here we compare the tsunami magnitude $M_{t}$ determined by Abe (http://www.eri.u-tokyo.ac.jp/topics/SUMATRA2004/ abe.html). Tsunami magnitude $M_{t}$ is computed from the tsunami amplitude, $H$ (in $\mathrm{m}$ ), recorded at a station at distance $X$ (in km) by the relation $M_{t}=\log H+\log X+5.55$ (Abe 1981). Despite its simplicity, this computation represents the overall size of tsunamis well, as shown in Table 1 . In most cases, $M_{t}$ and $M_{w}$ are close. An obvious exception is the 1946 Unimak Island (Aleutian Islands) earthquake, which exhibited a large difference between $M_{w}$ and $M_{t}$. This difference is generally attributed to the anomalous nature of the source, either extremely slow faulting or a large-scale ocean bottom slumping. The tsunami magnitude $M_{t}=9.1$ of the Great Sumatra-Andaman earthquake is close to 
Table 1. Tsunami magnitude, in relation to earthquake magnitude

\begin{tabular}{lcc}
\hline \hline \multicolumn{1}{c}{ Earthquake } & $M_{t}$ & $M_{w}$ \\
\hline 1946 Aleutians & 9.3 & 8.0 \\
1952 Kamchatka & 9.0 & 9.0 \\
1957 Aleutians & 9.0 & 8.6 \\
1960 Chile & 9.4 & 9.5 \\
1964 Alaska & 9.1 & 9.2 \\
2004 Great Sumatra-Andaman & 9.1 & 9.2 \\
\hline \hline
\end{tabular}

a Sources: Abe 1979 and http://www.eri.u-tokyo.ac.jp/topics/ SUMATRA2004/abe.html

its $M_{w}$ value, suggesting that the overall size of the tsunami generated by the Great Sumatra-Andaman earthquake is essentially what is expected of an $M_{w} \approx 9$ earthquake. Thus, even though the tsunami was extremely devastating, its physical size does not seem anomalously large. The impact of tsunamis on society depends upon not only the physical size but also many other factors, such as the total population and the preparedness in the affected areas.

\section{SHORT-PERIOD GROUND MOTION}

How strong was the ground motion of the Great Sumatra-Andaman earthquake? This is obviously an important question, but, as far as we know, there was no strong-motion recording in the rupture area, and no direct estimation of ground motion can be made. However, we can infer the overall strength of short-period motion from teleseismic data and compare it with that for other great earthquakes. Houston and Kanamori (1986) developed a short-period magnitude scale $\hat{m}_{b}$, which is similar to the short-period magnitude $m_{b}$ used by the U.S. Geological Survey (USGS), except that $\hat{m}_{b}$ is determined from the maximum amplitude of the entire P-wave train, instead of the first few seconds used in $m_{b}$. With the large number of high-quality global broadband stations, we could determine $\hat{m}_{b}$ accurately for the Great Sumatra-Andaman earthquake. The period range over which $\hat{m}_{b}$ is measured for great earthquakes is about $1-5 \mathrm{sec}$. Figure 4 shows the result. In general, $\hat{m}_{b}$ increases with $M_{w}$. It is not obvious, however, how $\hat{m}_{b}$ can be related to the absolute amplitude of short-period ground motion in the near field. Nevertheless, it is interesting to note that an $\hat{m}_{b}$ value of 7.25 for the Great Sumatra-Andaman earthquake is considerably lower than that given by the general trend defined by other large and great earthquakes. In comparison, $\hat{m}_{b}$ for the 28 March 2005 Nias, Sumatra earthquake $\left(M_{w}=8.6\right)$ is 7.26 and is comparable to that of the 2004 Great Sumatra-Andaman earthquake, even if $M_{w}$ is significantly smaller. Thus, as far as short-period waves are concerned, the Great Sumatra-Andaman earthquake was not exceptionally large. As mentioned earlier, $\hat{m}_{b}$ represents only the overall strength of short-period waves, and we cannot make a quantitative statement regarding the distribution of short-period ground motions in the rupture zone. Nevertheless, we can probably qualitatively conclude that 


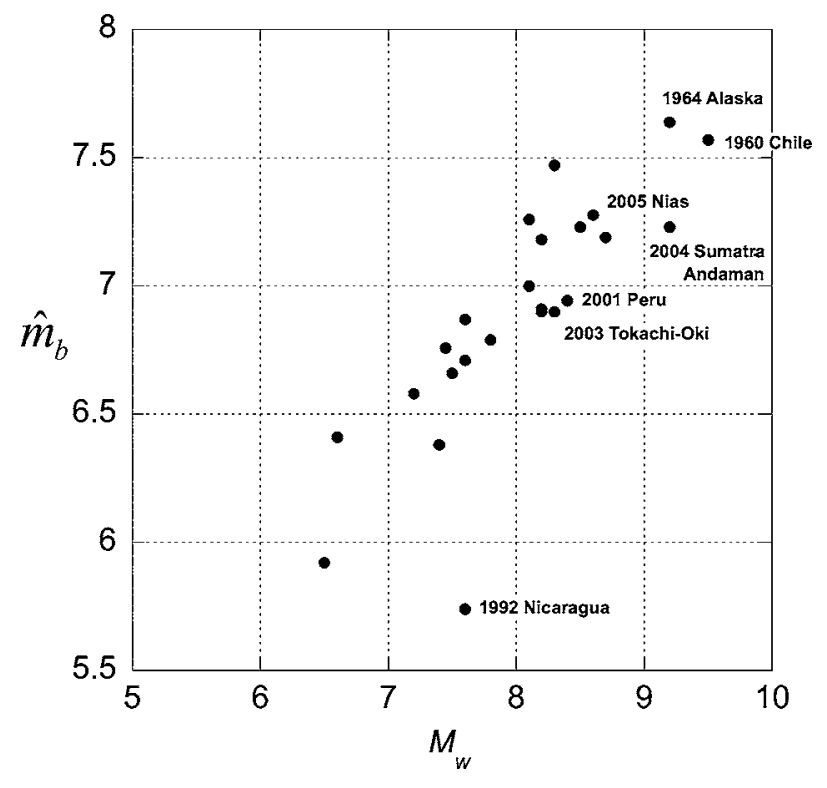

Figure 4. $\hat{m}_{b}$ versus $M_{w}$ for large and great earthquakes.

the strength of short-period ground motion in the rupture area of the Great SumatraAndaman earthquake is, overall, somewhat smaller than that of other great earthquakes such as the 1960 Chile and the 1964 Alaska earthquakes. We note here that, as shown in Figure 4, the 1992 Nicaragua earthquake (Kanamori and Kikuchi 1993), known as a slow tsunami earthquake-i.e., an earthquake that generates a tsunami disproportionately large for its seismic magnitude (Kanamori 1972) — had an $\hat{m}_{b}$ that is significantly smaller than that of earthquakes with a comparable $M_{w}$. Thus, the Great SumatraAndaman earthquake as a whole was not a slow tsunami earthquake, although it may have the character of slow tsunami earthquakes in some places in the rupture area.

\section{NIAS EARTHQUAKE}

On 28 March 2005, an $M_{w}=8.6$ earthquake occurred near Nias Island on the southeastern extension of the rupture zone of the Great Sumatra-Andaman earthquake. This zone ruptured in 1861 in a great earthquake, and the 2005 event is generally considered a repeat of the 1861 event. The tsunami magnitude $M_{t}$ of the 2005 event was 8.5 (Abe 2005).

\section{UNIQUE CHARACTERISTIC OF THE GREAT SUMATRA-ANDAMAN EARTHQUAKE}

The occurrence of such a large earthquake as the Great Sumatra-Andaman earthquake at this particular location was very surprising to many seismologists. In general, the past great earthquakes have occurred in the areas with certain tectonic characteristics 
(Uyeda and Kanamori 1979). First, the great earthquakes like the 1960 Chile and the 1964 Alaska earthquakes occurred on the plate boundary where the subducting oceanic plate is relatively young. The age of the subducting oceanic plate is about 20 million years for Chile and 40 million years for Alaska. When the subducting plate is young, it is more buoyant, thus leading to strong coupling between the subducting oceanic plate and the continental plate. In the case of the Great Sumatra-Andaman earthquake, the age of the subducting plate in the southernmost portion of the rupture zone is about 55 million years, which is relatively young, but in the northernmost portion, it is almost 90 million years old, which is much older than that of the subduction zones where great earthquakes have occurred.

Second, in the subduction zones where great earthquakes have occurred in recorded history, the trench-normal convergence rate is large, $11 \mathrm{~cm} / \mathrm{yr}$ for Chile and $6 \mathrm{~cm} / \mathrm{yr}$ for Alaska. In the case of the Great Sumatra-Andaman earthquake, the trench-normal convergence rate is about $3 \mathrm{~cm} / \mathrm{yr}$ in the south and almost $0 \mathrm{~cm} / \mathrm{yr}$ in the north. The relation summarized by Ruff and Kanamori (1980) suggests an empirical formula

$$
M_{w}=-0.00953 T+0.143 V+8.01
$$

where $M_{w}$ is the magnitude of the expected event, $V$ is the trench-normal convergence rate in $\mathrm{cm} / \mathrm{yr}$, and $T$ is the age of the subducting plate in millions of years (Kanamori 1986). Using this relationship, we get $M_{w}=8.2$ for the southernmost part of the rupture zone of the Great Sumatra-Andaman earthquake. Thus, in terms of this empirical relationship, an occurrence of an $M_{w}=8+$ earthquake in the southernmost part of the rupture zone of the Great Sumatra-Andaman earthquake is not unexpected, but it is surprising to have an $M_{w}=9+$ event. Then what is special about the Great Sumatra-Andaman earthquake? Why was there such a large earthquake at the place where we did not expect very large events? The empirical relationship as used above may approximately apply in the general sense, but significant deviations can occur in complex systems such as earthquakes, where interactions between different segments cause the triggering of rupture over an extended area. Although an explanation of exactly how different parts of the rupture zones interacted during the Great Sumatra-Andaman earthquake sequence must await further investigation, it is possible that the rupture in the southernmost segment triggered the ruptures in the north. Such triggering may not happen all the time. If it does not happen, then the event may end up as a moderate-to-large earthquake, but if it does happen, then the event may become a great earthquake. As a result of this, the rupture pattern along a given subduction boundary can vary from sequence to sequence. One notable example of this variability is the sequence along the Nankai trough in southwest Japan (Imamura 1928, Ando 1975). Along the Nankai trough, there are several segments where large earthquakes are known to have occurred repeatedly. In 1707, two of the segments ruptured simultaneously, producing one of the largest earthquakes in Japan. In 1854, the same two segments ruptured 32 hours apart, producing two $M$ $=8+$ earthquakes. In 1944 and 1946, the two segments ruptured about two years apart, each producing an $M \approx 8$ earthquake. It would be very difficult to predict exactly how the different segments rupture and how they interact. This kind of unpredictability is inevitable for complex processes such as earthquakes. 
Diagnostics of Tsunami Potential

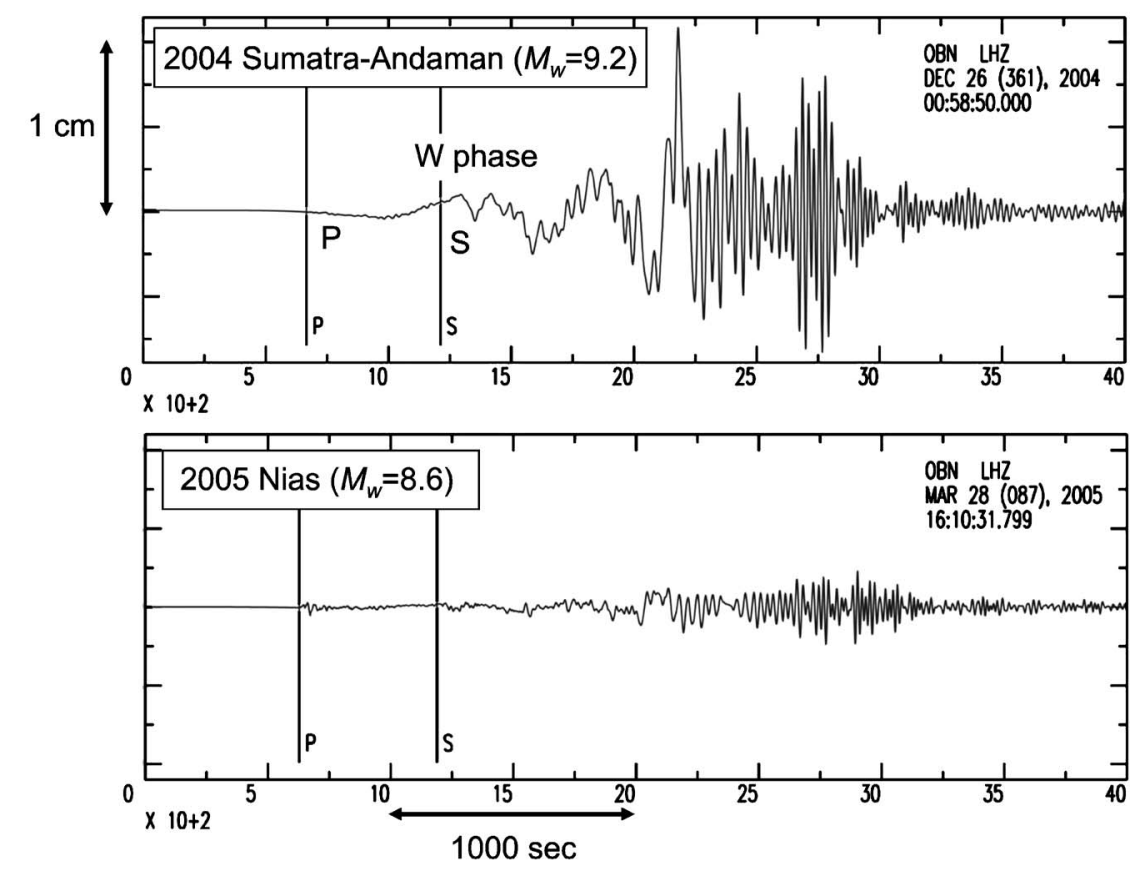

Figure 5. Comparison of the displacement seismograms of the 2004 Great Sumatra-Andaman earthquake $\left(M_{w}=9.2\right)$ and the 2005 Nias earthquake $\left(M_{w}=8.6\right)$ on the same scale.

\section{DISCUSSION AND CONCLUSION}

As described above, the 2004 Great Sumatra-Andaman earthquake was among the greatest earthquakes in many ways. With the availability of high-quality global seismic data, seismologists could quantitatively determine many of the important physical characteristics of this earthquake.

Although the Great Sumatra-Andaman earthquake was an extremely large event, it took seismologists some time to recognize how large the event really was, partly because the present global observation systems are not necessarily designed for such "off-scale" events (Kerr 2005). A very rapid determination of the size is useful for various warning purposes, such as tsunami warnings. Needless to say, to establish an effective tsunami warning system, a comprehensive program is necessary; it should include the monitoring of seismic waves and water waves, infrastructure for information transfer, and logistics, as well as the education and training of residents. Here, we suggest a simple method that can rapidly distinguish truly great earthquakes from large earthquakes. Figure 5 compares very-long-period displacement seismograms, one from the 2004 Great Sumatra-Andaman earthquake (i.e., a truly great earthquake), and the other from the nearby 2005 Nias earthquake (i.e., a large earthquake). The difference in the amplitude 
of the very-long-period wave (500-1,000 sec.) preceding the $S$ wave is apparent. This long-period wave is the $W$ phase, which can be interpreted as a superposition of overtone Rayleigh waves (Kanamori 1993). This phase can be effectively used for identifying events larger than $M_{w}=9$. If $M_{w} \geqslant 9$, then the event is most likely a subduction-zone event and will almost certainly produce a large tsunami. As mentioned above, how this information is to be used for practical purposes should be considered in the context of a more comprehensive system. Here, we present this as an important seismological characteristic of truly great earthquakes.

\section{ACKNOWLEDGMENT}

The preparation of this manuscript was done while I was visiting at the Disaster Prevention Research Institute, Kyoto University, under the support of the Eminent Scientists Award Program of the Japan Society of Promotion of Science. We used the Global Seismic Network seismograms of the Incorporated Research Institutions for Seismology.

\section{APPENDIX: NOTE ON $M_{w}$ OF THE GREAT SUMATRA-ANDAMAN EARTHQUAKE}

For the Great Sumatra-Andaman earthquake, different values of seismic moment, $M_{0}$, have been obtained by different investigators using different data sets and assumptions: $M_{0}=3.95 \times 10^{22} \mathrm{Nm}$ (Harvard CMT, http://www.seismology.harvard.edu/), $M_{0}$ $=6.5 \times 10^{22} \mathrm{Nm}$ (Ammon et al. 2005), $M_{0}=1.0 \times 10^{23} \mathrm{Nm}$ (Stein and Okal 2005), $M_{0}$ $=1.17 \times 10^{23} \mathrm{Nm}$ (Tsai et al. 2005), and $M_{0}=8.8 \times 10^{22} \mathrm{Nm}$ (Subarya et al. 2006). The last value is from the static displacement data. The computation of $M_{w}$ from $M_{0}$ involves a rounding-off error that depends on the specific $M_{0}$ versus $M_{w}$ relationship used. Here, the relation given in Kanamori (1978), $M_{w}=\left(\log M_{0} / 1.5\right)-10.7\left(M_{0}\right.$ in dyne-cm), is used, and $M_{w}$ is rounded off to two digits. Then, $M_{w}=9.0,9.2,9.3,9.3$, and 9.3, corresponding to the $M_{0}$ values listed above.

One of the reasons for the difference is that, in the source inversion of shallow lowangle thrust earthquakes, we cannot tightly constrain $M_{0}$ and the dip angle $\delta$ separately; we can determine well only the product $M_{0} \sin (2 \delta)$ (e.g., Kanamori and Given 1981). Since the dip angle $\delta$ is not determined well in any of the inversions, the $M_{0}$ values obtained are subject to large uncertainties. Furthermore, the 3-D structure near the source has a strong influence on the determination of $M_{0}$, but a simple 1-D structure (i.e., a laterally homogeneous layered structure) is used in all the inversion studies. Thus, the values of $M_{0}$ could be systematically biased. In this paper, we use $M_{w}=9.2$ consistently, but any value between 9.1 and 9.3 is acceptable.

\section{REFERENCES}

Abe, K., 1979. Size of great earthquakes of 1837-1974 inferred from tsunami data, J. Geophys. Res. 84, 1561-1568.

Abe, K., 1981. Physical size of tsunamigenic earthquakes of the Northwestern Pacific, Phys.

Earth Planet. Inter. 27 (3), 194-205.

Abe, K., 2005. Personal communication. 
Abe, K. http://www.eri.u-tokyo.ac.jp/topics/SUMATRA2004/abe.html

Ammon, C. J., Ji, C., Thio, H.-K., Robinson, D., Ni, S., Hjorleifsdottir, V., Kanamori, H., Lay, T., Das, S., Helmberger, D., Ichinose, G., Polet, J., and Wald, D., 2005. Rupture process of the 2004 Sumatra-Andaman earthquake, Science 308 (5725), 1133-1139.

Ando, M., 1975. Source mechanisms and tectonic significance of historical earthquakes along the Nankai trough, Japan, Tectonophysics 27, 119-140.

Harvard CMT, http://www.seismology.harvard.edu/

Houston, H., and Kanamori, H., 1986. Source spectra of great earthquakes, teleseismic constraints on rupture process and strong motion, Bull. Seismol. Soc. Am. 76, 19-42.

Hudnut, K., 2006. Geologic and geodetic aspects of the December 2004 Great SumatraAndaman earthquake and 2005 Nias-Simeulue earthquake, 2004 Great Sumatra Earthquakes and Indian Ocean Tsunamis of December 26, 2004 and March 28, 2005, Earthquake Spectra 22 ( $\mathrm{S} 3$ ), June (this issue).

Imamura, A., 1928. On the seismic activity of central Japan, Japanese J. Astronomy Geophys. 6, 119-137.

Ishii, M., Shearer, P. M., Houston, H., and Vidale, J. E., 2005. Extent, duration and speed of the 2004 Sumatra-Andaman earthquake imaged by the Hi-Net array, Nature 435 (7044), 933936.

Kanamori, H., 1972. Mechanism of tsunami earthquakes, Phys. Earth Planet. Inter. 6, 346359.

Kanamori, H., 1978. Quantification of earthquakes, Nature 271, 411-414.

Kanamori, H., 1986. Rupture process of subduction-zone earthquakes, Ann. Rev. Earth Planet Sci. 14, 293-322.

Kanamori, H., 1993. W phase, Geophys. Res. Lett. 20, 1691-1694.

Kanamori, H., and Given, J. W., 1981. Use of long-period surface waves for rapid determination of earthquake-source parameters, Phys. Earth Planet. Inter. 27, 8-31.

Kanamori, H., and Kikuchi, M., 1993. The 1992 Nicaragua earthquake-A slow tsunami earthquake associated with subducted sediments, Nature 361, 714-716.

Kerr, R. A., 2005. South Asia tsunami-Failure to gauge the quake crippled the warning effort, Science, 307, 201-201.

Lay, T., Kanamori, H., Ammon, C. J., Nettles, M., Ward, S. N., Aster, R. C., Beck, S. L., Bilek, S. L., Brudzinski, M. R., Butler, R., DeShon, H. R., Ekstrom, G., Satake, K., and Sipkin, S., 2005. The great Sumatra-Andaman earthquake of 26 December 2004, Science 308 (5725), $1127-1133$.

Ni, S., Kanamori, H., and Helmberger, D., 2005. Seismology-Energy radiation from the Sumatra earthquake, Nature 434 (7033), 582-582.

Park, J., Song, T. R. A., Tromp, J., Okal, E. A., Stein, S., Roult, G., Clevede, E., Laske, G., Kanamori, H., Davis, P., Berger, J., Braitenberg, C., Van Camp, M., Lei, X., Sun, H. P., Xu, H. Z., and Rosat, S., 2005. Earth's free oscillations excited by the 26 December 2004 Sumatra-Andaman earthquake, Science 308 (5725), 1139-1144.

Ruff, L., and Kanamori, H., 1980. Seismicity and the subduction process, Phys. Earth Planet. Inter. 23, 240-252. 
Stein, S., and Okal, E. A., 2005. Speed and size of the Sumatra earthquake, Nature 434 (7033), 581-582.

Subarya, C., Chlieh, M., Prawirodirdjo, L., Avouac, J-P., Bock, Y., Sieh, K., Meltzner, A. J., Natawidjaya, D. H., and McCaffrey, R., 2006. Plate-boundary deformation of the great Aceh-Andaman earthquake, Nature (in press).

Tsai, V. C., Nettles, M., Ekstrom, G., and Dziewonski, A. M., 2005. Multiple CMT source analysis of the 2004 Sumatra earthquake, Geophys. Res. Lett. 32 (17) L17304, doi:10.1029/ 2005 GL023813.

Uyeda, S., and Kanamori, H., 1979. Back-arc opening and the mode of subduction, J. Geophys. Res. 84, 1049-1061.

(Received 6 December 2005; accepted 11 April 2006) 